\title{
The Export of Agricultural Products of China in the Context of the Belt and Road Initiative
}

\author{
Lijing Wu \\ North China University of Technology \\ Beijing, China 100144
}

\author{
Yanxiao Geng \\ North China University of Technology \\ Beijing, China 100144
}

\begin{abstract}
At present, China's agricultural product trade is facing the development dilemma. The trade deficit is expanding, market and product structure is irrational, and the Chinese agriculture products often encounter trade barriers. "B\&R" initiative provides a rare opportunity for the development of agricultural products in China. It is necessary to seize this opportunity to change idea and innovate upon mechanism so as to increase the added value of exported agricultural products through various channels. There is also a need to develop electronic commerce, and make full use of interconnectivity and trade facilitation in "B\&R" initiative to develop the international trade of agricultural products.
\end{abstract}

Keywords-"B\&R" initiative; Agricultural products; International trade

\section{INTRODUCTION}

On September 7, 2013, Chinese President Xi Jinping delivered an important speech in Kazakhstan, and proposed building "Silk Road Economic Belt". In October, Xi also raised the strategic concept of "The 21st-Century Maritime Silk Road". These two important strategic ideas are called the "B\&R" initiative which has been included in Decisions of the CPC Central Committee on Comprehensively Deepening Reform and Several Other Important Issues, rising to national strategy. In the context of "B\&R" initiative, China's agricultural global strategy will also get a rare opportunity for development. The agricultural global strategy covers agricultural trade, investment, technology transfer, financial services and other areas, and this paper only discusses the impact of "B\&R" initiative on the international trade of agricultural products.

\section{CurRent Situation And Plight of China's}

\section{INTERNATIONAL TRADE OF AGRICULTURAL PRODUCTS}

\section{A. Sluggish Export of Traditional Competitive Agricultural Products and Expanding Trade Deficit}

According to the analysis of Agricultural Trade Promotion Center of the Ministry of Agriculture, China's agricultural trade has continued to grow rapidly in recent years, and the trade deficit is rapidly expanding. From a general trend, China is moving into a net importing period of bulk agricultural products, and the number of agricultural products imported is increasing sharply with great price volatility, while the export growth of traditional agricultural products is slow. For a long time, the advantages of China's export of agricultural products mainly lie in low cost and low price, and the added value of export products is low. With the increasing resource and environmental constraints on China's agricultural development, the rising costs of labor, land and inputs as well as continued appreciation of the $\mathrm{RMB}$, have continued to weaken the traditional competitive price advantage of agricultural exports. There are fluctuations in export of aquatic products, and vegetable exports increase slowly with low added value. The export volume of fruits even declines, which indicates that the export of China's traditional competitive products is sluggish.

\section{B. Irrational Agricultural Market Structure and High Market Concentration}

In the early period of accession to the WTO, agricultural exports are mainly concentrated in Japan, Hong Kong, South Korea and other neighboring countries (regions) as well as Europe, the United States and other developed countries (regions). In recent years, China and the emerging market economies continue to strengthen communication and exchange with developing countries, and the agricultural trade with some countries (such as Brazil, Mexico and other South American countries; Ukraine, Russia, Turkey and other Central Asian countries; Israel, Saudi Arabia and other Middle East countries; Egypt, South Africa and other African countries) grows rapidly. The growth rate of agricultural trade with these countries is generally higher than the overall growth rate of China's agricultural trade. In this context, China's agricultural export market has been diversified, and the proportion of exports to Japan, South Korea and Hong Kong has declined, but the overall export concentration remains high. The high concentration of export market has restraining effect on diversified development of China's agricultural trade. In terms of import, due to concentration of origin of imported products and other factors, the degree of import market concentration does not fall but climb. During 2001-2011, the proportion of imports of agricultural products from the United States, ASEAN, Australia, Argentina, the European Union and Brazil to total imports of agricultural products was increased from $71.1 \%$ to $76.9 \%$. The import market concentration is high, which will increase instability factors affecting the domestic food security.

\section{Irrational Agricultural Products for Export and Too Low Added Value}

From the product structure, in China's agricultural products for export, preliminarily processed products 
account for $80 \%$, while deep-processed products account for only $20 \%$. In terms of value, the value as well as added value of deep-processed products is much greater than that of preliminarily processed products. This unreasonable phenomenon affects the overall quality and benefits of China's agricultural trade. In agricultural products for export, the low-quality, low-price and low-popularity agricultural products dominate the market, which does not meet the requirements of modern agriculture and brand agriculture.

\section{New Trade Barriers to the Export of Agricultural Products}

The developed member states attach great importance to the safety of imported food, and are very strict about the restrictions on pesticide residue and other detection indicators. China's annual export of agricultural products is often banned due to the green barriers, suffering serious losses. In addition, with increasing international agricultural trade market competition, all countries constantly conduct innovation and increase the types of trade barriers. Especially the development of foreign genetic engineering techniques has produced an enormous real and potential impact on the traditional agricultural trade, which will greatly weaken the agricultural trade competitiveness of China mainly dependent on the traditional agricultural trade.

\section{OPPORTUNITIES}

\section{A. Connotation and Goal of the "B\&R" Initiative}

The "B\&R" initiative is a concept of co-development, rather than an entity. It mainly relies on the existing bilateral and multilateral mechanisms between China and the relevant countries, and draws on the regional cooperation platform to promote cooperation and development. At the same time, the "B\&R" initiative borrows the historical symbol of the ancient Silk Road, and advocates peace and development. It aims to actively develop the economic partnership with the countries along Silk Road, and its vision is to work with all parties to build the culturally inclusive community of interests, destiny and responsibility with political mutual trust and economic integration. The goal of the "B\&R" initiative is to create the world's largest platform for cooperation and development, in order to promote the free flow of economic factors, efficient allocation of resources and in-depth market integration, and promote the countries along "B\&R" to achieve coordination of economic policies.

\section{$B$. The Impact of the " $B \& R$ " Initiative on International Trade of Agricultural Products}

1) It helps to expand export scale of agricultural products: In recent years, some of China's agricultural products have encountered a serious overcapacity problem. For example, according to statistics of China Tea Circulation Association, about more than one-third of China's tea products are in an oversupply state after deducting total exports and domestic sales of tea products. The oversupply and poor sale of agricultural products directly affect the economic interests of farmers, and the "B\&R" initiative provides a good opportunity to solve this problem. Trade cooperation is the key content of the "B\&R" initiative, and all countries along "B\&R" will focus on research to solve the issue of trade facilitation, eliminate trade barriers, especially all kinds of hidden non-tariff barriers, build a good business environment, and actively establish free trade area with countries and regions along "B\&R" so as to release potential for cooperation and promote the development of free trade. China and many countries along "B\&R" are highly complementary in the area of agricultural products, such as the ASEAN countries and the five Central Asian countries. The "B\&R" initiative makes China's agricultural products obtain a broader international market, helps to solve the domestic excess capacity problem and increase farmers' income.

2) It helps to adjust agricultural structure and develop international cooperation in capacity: Many countries along "B\&R" are developing countries, lagging behind China in terms of agricultural economic and technological level, so it is feasible and realistic to carry out international capacity cooperation in the agricultural areas. For some industries reduced to sunset industries in China, they still have some room for development in other countries along "B\&R". Through capacity cooperation and industrial strategic shift, on the one hand, it can help other countries to improve their technical level and develop national agricultural economy; on the other hand, it can make China successfully achieve industrial upgrading and updating, as well as rational adjustment of agricultural structure. In international agricultural trade, China should give play to its comparative advantages to focus on the development of technologyintensive products, especially deep-processed agricultural products, in order to increase the added value of agricultural products, and complete the upgrading and transformation of agricultural production while obtaining greater economic benefits.

3) It helps to achieve import market diversification and promote domestic food security: As mentioned above, China and other countries along "B\&R" have strong trade complementarities in agricultural areas, for example, the five Central Asian countries have a comparative advantage in the export of grain and cotton and other land-intensive products, while they are at a disadvantage in the processed foods with agricultural products as raw materials and other labor and capital-intensive products. In contrast, China has a comparative advantage in the export of the processed foods and other labor and capital-intensive products, while the imports of disadvantaged land-intensive products gradually increase. In the future, the domestic food supply and demand conflicts have become increasingly prominent. As far as "moderate import" is concerned, we can consider expanding import of food from the countries along "B\&R". These countries respond positively to China's "B\&R" initiative, and some countries and China have signed a memorandum of cooperation for the "B\&R" initiative. Some neighboring countries sign a memorandum of regional cooperation and border cooperation as well as long-term 
development plan of economic and trade cooperation. The economic link between these countries and China will be closer, the regional integration intensifies and the areas of agricultural production have a greater potential for development. Increasing the import of food and other superior agricultural products from the countries along "B\&R" can help to ensure China's domestic food security.

\section{RECOMMENDATIONS}

\section{A. Increasing the Added Value of Agricultural Products for Export through A Variety of Ways}

To develop the export of agricultural products and optimize the export structure of agricultural products, it is necessary to upgrade and optimize the industrial structure; focus on deep processing of agricultural products, and raise the technology-intensive level of agricultural products in order to achieve higher added value of products. For primary products, we should not simply pursue the export volume and increase sales by low prices. Meanwhile, China's "amber box" subsidies to agriculture have been close to the ceiling promised during the accession to WTO. It means that the original model of agricultural production is unsustainable and it is bound to be reformed. For primary agricultural products, it is necessary to strengthen brand awareness and brand strategy, focus on the development, publicity and promotion of famous products, specialties and green products, and develop the historical and cultural value attached to agricultural products, so as to develop modern agriculture and brand agriculture. For deep-processed agricultural products, it is necessary to change the agricultural production structure according to the market demand changes of agricultural products. At the same time, we can make use of the opportunity provided by the "B\&R" initiative, and draw on China's advantages in capital and technology, to carry out industrial restructuring and expand the agricultural products with a comparative advantage.

\section{B. Positively Developing Cross-border E-commerce of Agricultural Products}

There are many difficulties in traditional agricultural trade patterns such as market supply and demand asymmetry, high transaction costs and slow cash flow, and these problems can be solved by carrying out the e-commerce of agricultural products. By e-commerce transaction, the information transmission will be more efficient, capital turnover will be quicker, and the transaction procedures and processes will be more convenient, thereby reducing transaction costs and increasing trading opportunities, which provides technical support for the expansion of production scale of agricultural products. At the same time, network technology enables the production and sale channels of agricultural products to be wider and farmers' income is improved significantly. The "B\&R" initiative provides a rare opportunity for the development of e-commerce and especially cross-border e-commerce, and agricultural trade should also conform to this trend and seize this opportunity to share the development dividend of informatization and modernization. In order to promote agricultural e-commerce, the state should accelerate the improvement of e-commerce legislation, and the grass-roots government should speed up communication infrastructure construction, popularize network knowledge and network marketing philosophy, and guide and support the construction of high-level e-commerce platform, so that farmers can effectively benefit from it.

\section{Taking Full Advantage of the Interconnectivity and Trade Facilitation Measures in the " $B \& R$ " Initiative}

Agricultural trade and logistics have a high demand on cold chain transportation, and logistics transportation is dependent on infrastructure construction. In this regard, it can make use of the construction achievements of the "B\&R" initiative. In the future, the regions along "B\&R" will conduct large-scale infrastructure construction, and good transportation and communication facilities can lay a solid foundation for the smooth development of international agricultural trade. In addition, in order to carry out regional cooperation, it is necessary to reduce the cost of trade and investment within the region, and promote logistics, trade and investment facilitation. It is a global trend and the key to the development of regional economic cooperation. The "B\&R" initiative should attach great importance to promoting trade and investment facilitation and improving the cooperation in custom, transportation, entry-exit inspection and quarantine, finance, information exchange and other functional areas. These measures will contribute to the promotion of international trade of agricultural products.

\section{CONCLUSION}

In short, the "B\&R" initiative will promote China to build a new pattern of all-round opening, provide new impetus for the Chinese economy and the world economy, optimize and innovate the international cooperation and global governance mechanism, and bring new opportunities for China's agricultural development.

\section{REFERENCES}

[1] Hongyuan Xu, Yijun Han, Jianlei Han,etc. Analysis on the Trend of Agricultural Product Trade in China in Recent Years,[DB/OL].http://www.caaa.cn/show/newsarticle.php?ID=36145 2

[2] Xiangpeng Lou. The Belt and Road Initiative: New Opportunities of Modern Agriculture[J]. Jiangxi Agriculture, 2015,4:1

[3] Guogiang Cheng. China Agricultural Development under the Background of Belt and Road Initiative[J]. Agriculture Economics, 2015,7:74

[4] Haixia Guo, Lingqiu Kong. On the Legal Protection of E-Commerce in China[J]. Knowledge Economy, 2015,7:96

[5] Yun Zhang, Guang Yang, Yang Yang. The Belt and Road Initiative: Strengthening Agricultural Cooperation Between China and Central Asia[J]. International Economic Cooperation, 2015,1: 31-32 